\title{
Preventive Measures in the Criminal Procedural System in Romania
}

\author{
Alexandru Peicea \\ “Alexandru Ioan Cuza” Police Academy, Bucharest, Romania, alexandru.peicea@gmail.com
}

\begin{abstract}
Preventive measures are those measures ordered by the judicial bodies in order to ensure the proper conduct of the process and the participation of suspects or defendants in the judicial proceedings. Preventive measures shall also be ordered against persons committing criminal offences and where it is desirable that such persons do not influence witnesses or injured persons, experts or other participants in the criminal proceedings. The Code of Criminal Procedure in Romania regulates five preventive measures: taking in custody, judicial control, judicial control on bail, house arrest and pre-trial arrest. The present work aims to address preventive measures from a theoretical perspective, and we will analyze the conditions of ordering such preventive measures, remedies that may be formulated against these measures, the possibilities for revocation or termination of such measures in certain situations, but also the actual content of such measures.
\end{abstract}

KEYWORDS: conditions, duration, preventive measures, purpose, revocation, termination

\section{Introduction}

Preventive measures are compulsion measures that may be taken by the judicial bodies in order to ensure the proper conduct of the criminal process, in order to prevent the abstraction of the suspect or defendant from prosecution or from judgment or in order o prevent the committing of new offences. The Code of Criminal Procedure in Romania governs a number of five preventive measures: taking in custody, judicial control, judicial control on bail, house arrest and pre-trial arrest. Of these, three are custodial preventive measures (taking in custody, house arrest, pre-trial arrest) and two are restrictiverights preventive measures (judicial control and judicial control on bail). With regard to the purpose of the preventive measures, these apply in particular to natural persons, but where the criminal liability engagement for legal persons is possible, the Code of Criminal Procedure regulates measures which can also be taken against the latter (Code of Criminal Procedure commented, coord. Volonciu, 2017, 494).

\section{Purpose and general conditions for the application of preventive measures}

According to art. 202 of the Code of Criminal Procedure: "Preventive measures may be ordered if there is evidence or probable cause leading to a reasonable suspicion that a person committed an offense and if such measures are necessary in order to ensure a proper conducting of criminal proceedings, to prevent the suspect or defendant from avoiding the criminal investigation or trial or to prevent the commission of another offense". The purpose of the preventive measures is, in fact, the danger which must be mandatory prevented, the judicial bodies having the obligation to choose the most appropriate, necessary and appropriate measure for this purpose to be carried out to fulfilment. In order for a preventive measure to be ordered by the judicial bodies towards the suspect or the defendant, a number of conditions must be met, namely:

a) There is evidence or a thorough indication that a person has committed a criminal offence. In relation to this condition, the following aspects are to be retained: Preventive measures may be ordered both against the suspect (taking in custody) and the defendant (any preventive measure); The evidence underlying the undertaking of a preventive measure towards a person must not be as strong as the evidence on which a conviction would be based, in the latter case being absolutely necessary for the evidence administered in question to lead the court to a conviction beyond any doubt that the deed was committed by the defendant with the guilt provided by the law and that there is no cause for removing the criminal liability; the need for 
evidence to take a preventive measure is justified since the fulfilment of that condition avoids the arbitrariness of the judicial bodies in the ordering of those measures;

b) The measure chosen is proportionate to the seriousness of the accusation. Regarding this condition the following clarifications are necessary: the criteria for assessing the seriousness of an act are not provided for by the criminal procedural law. However, it is obvious that this gravity must be objectively assessed, both in abstract, but especially in concrete terms. The seriousness of the act may be assessed by reference to the means used by the suspect or defendant, the result produced by the performance of the offence, but also aspects regarding the person of the suspect or defendant, referring specifically to the his/her criminal record.

The preventive measure must be necessary. With regard to the need to take, prolong or maintain a preventive measure towards a person, it is to be noted that it cannot and should not be deducted from the mere declaration by the judicial body of those purposes. The need to order a preventive measure must arise from the fear of the judicial body that the person who committed the offence may commit another, in this situation the risk being necessary to be prevented. Whenever the undertaking, extension or preservation of a preventive measure is ordered, it is necessary for the judicial body to ascertain whether or not there are any grounds preventing the initiation or the exercise of criminal proceedings.

\section{Preventive measures seen in their specificity}

\section{Taking in custody}

The taking in custody is that custodial preventive measure which is ordered for a maximum period of 24 hours. Within the period of detention, the time required for the dispatching of the suspect or defendant at the headquarters of the judicial body may not be included.

The preventive measure of taking in custody shall be the only preventive measure which may be ordered only in the course of the prosecution, which may also be ordered by the criminal investigation body and shall be the only preventive measure which may be available to the suspect. The taking in custody shall not be confused with the apprehension and presentation of the perpetrator before the judicial bodies or the institution of the warrant for arrest.

The taking in custody may be ordered against a person where there is evidence that the person has committed an act provided for by the criminal law, where the measure is necessary and proportionate to the seriousness of the act and when there is no case of impeachment of the initiation of criminal proceedings. (Criminal action may not be initiated, and when it has already been initiated, may not be used if: a) the action in question does not exist; b) the action is not covered by the criminal law or was not committed with the guilt required by law; c) there is no evidence that a person committed the offense; d) there is a justifying or non-imputability cause; e) a prior complaint, an authorization or seizure of the body of competent jurisdiction or other requirement set by the law, required for the initiation of criminal action, is missing; f) amnesty or statute of limitations, or death of a natural-person suspect or defendant occurred or de-registration of a legal-entity suspect or defendant was ordered; g) a prior complaint was withdrawn, for offenses in relation to which its withdrawal removes criminal liability, reconciliation took place or a mediation agreement was concluded under the law; h) there is a non-penalty clause set by the law; i) double jeopardy (res judicata); j) a transfer of proceedings with a different country took place under the law). It is important to specify that the measure of taking in custody may be made ordered against a person also when there are reasonable indications that that person has committed an act provided for by the criminal law. The procedural-criminal law does not provide a definition of the notion of reasonable indications, but in order to edify ourselves we can make appeal to the case-law of the European Court of Human Rights. Thus, by the existence of reasonable indications we understand "The existence of data, information leading an objective and impartial observer [to the conclusion] that the person investigated may have committed the offence with which he/she is accused" (Causes Gusyinski v. Russia, Tuncer and Durmuș v. Turkey, Jecius v. Lithuania). 
As we have indicated above, the taking in custody measure can only be ordered against the suspect or defendant. Thus, in order the taking in custody measure against a person to be ordered, it is necessary not only to initiate the prosecution but also the pursuing of the prosecution against the suspect to be ordered. If the judicial body decides to order a person's taking in custody, it has the obligation to examine him/her. The obligation of hearing a person does not imply the constraining of the person to give a statement in question as any person to whom an accusation is brought may prevail herself/himself of the right to silence, enshrined in the Romanian criminal procedure law at art. 83. The judicial bodies are obliged to proceed to the hearing of the person before ordering a preventive measure against the person.

The procedural act of ordering the taking in custody measure shall bear the name of order. The measure shall be enforceable from the moment the order is issued. It is to be noted that the order by which the taking in custody of a person is ordered must be reasoned. Unlike the other custodial preventive measures, in the case of taking in custody, the law does not require the judicial body to issue a mandate to execute the preventive measure. The taking in custody measure shall be communicated in writing to the person restrained by the communication of a copy of the order by which the taking in custody was ordered.

Against the order by which the taking in custody of the suspect or defendant was ordered, he/she may submit a complaint, remedy to be resolved by the prosecutor supervising the prosecution, and in the event that the prosecution is carried out in a compulsory way by the prosecutor, the body called to order the complaint lodged by the suspect or defendant shall be the hierarchically superior prosecutor.

\section{Judicial control}

The judicial control is a restrictive preventive measure of rights that may be ordered according to the procedural phase by the Prosecutor, the Judge for Rights and Liberties, the Preliminary Chamber Judge or by the court. It is to be noted that in the criminal prosecution phase, the prosecutor is the one who orders the measure of judicial control against the defendant but, as an exception, also the Judge for Rights and Liberties has this possibility when rejecting the proposal of the prosecutor of imposing a more severe preventive measure, reasonably appreciating that the measure of judicial control is necessary but also appropriate for the criminal process to be carried out under normal conditions.

In order the preventive measure of judicial control to be ordered against a defendant it is necessary the following conditions to be fulfilled:

a) The existence of evidence based on which the reasonable suspicion to be drawn that a person has committed a criminal offence

b) There are no cases of impeachment of the initiation of the criminal proceedings;

c) The measure of the judicial control must be necessary and sufficient for the purpose pursued by its performance.

The judicial control may be ordered against a person based on an order issued by the prosecutor or by a resolution of the Judge for Rights and Liberties, the Preliminary Chamber Judge or by the court. The order or, where appropriate, the resolution shall be reasoned and communicated to the defendant against whom the measure of judicial review was ordered. The defendant may challenge the prosecutorial order issued by the prosecutor, the decision of the Judge for Rights and Liberties, of the Preliminary Chamber Judge or of the court.

While under judicial control, a defendant shall comply with the following obligations:

a) to appear before the criminal investigation body, the Preliminary Chamber Judge or the court any time they are called;

b) to inform forthwith the judicial bodies having ordered the measure or with which their case is pending on any change of domicile;

c) to appear before the law enforcement body appointed to supervise them by the judicial bodies having ordered the measure, according to the supervision schedule prepared by the law enforcement body or whenever they are called. 
Judicial bodies having ordered the measure may require that the defendant, during the judicial control, comply with one or more of the following obligations:

a) not to exceed a specific territorial boundary, set by the judicial bodies, without their prior approval;

b) not to travel to places set specifically by the judicial bodies or to travel only to places set by these;

c) to permanently wear an electronic surveillance system;

d) not to return to their family's dwelling, not to get close to the victim or the members of their family, to other participants in the committed offense, witnesses or experts or to other persons specified by the judicial bodies and not to communicate with these in any way, be it directly or indirectly;

e) not to practice a profession, craft or activity during the practice or performance of which they committed the act;

f) to periodically provide information about their living means;

g) to subject themselves to medical examination, care or treatment, in particular for the purpose of detoxification;

h) not to take part in sports or cultural events or to other public gatherings;

i) not to drive specific vehicles established by the judicial bodies;

j) not to hold, use or carry weapons;

k) not to issue cheques (art. 215 of the Romanian Code of Criminal Procedure).

\section{Judicial control on bail}

The judicial control on bail has the same content as the measure of judicial control, the major difference between these measures being that in the case of the judicial control on bail on the defendant is imposed the obligation to pay an amount by way of guaranteeing the participation of the defendant in the criminal proceedings and the fact that he/she will no longer commit other offences.

\section{House arrest}

It is the custodial preventive measure consisting of the obligation imposed on the defendant not to leave for a specified period of time the property in which he/she resides without the permission of the judicial body which has ordered the measure or with which the cause is pending and to obey the restrictions set by it. House arrest may be ordered against the defendant only by the Judge for Rights and Liberties, the Preliminary Chamber Judge or by the court. It is to be noted that the measure of house arrest cannot be ordered against a person who has committed an offence on a family member or who has previously committed the offence of escape.

The measure of house arrest can only be taken if the following conditions are met:

a) The defendant fled or went into hiding in order to avoid the criminal investigation or the trial, or made preparations of any nature whatsoever for such acts;

b) The defendant tries to influence another participant in the commission of the offence, a witness or an expert to destroy, alter, conceal, or to steal physical evidence or to cause another person to adopt such a behaviour;

c) A defendant exerts pressures on the victim or tries to reach a fraudulent agreement with $\mathrm{him} / \mathrm{her}$;

d) There is reasonable suspicion that, after the initiation of the criminal action against him/her, the defendant committed a new offense with intent or is preparing to commit a new offense.

The measure of house arrest can also be ordered if the evidence generate reasonable suspicion that they committed an offense with direct intent against life, an offense having caused bodily harm or death of a person, an offense against national security as under the Criminal Code and other special laws, an offense of drug trafficking, weapons trafficking, trafficking in human beings, acts of terrorism, money laundering, counterfeiting of currency or other securities, blackmail, rape, 
deprivation of freedom, tax evasion, assault, judicial assault, the offense of corruption, an offense committed through electronic communication means or another offense for which the law requires a penalty of no less than 5 years of imprisonment and, based on an assessment of the seriousness of facts, of the manner and circumstances under which it was committed, or on the entourage and the environment from where the defendant comes, of their criminal history and other circumstances regarding their person, it is decided that their deprivation of freedom is necessary in order to eliminate a threat to the public order (LegeAZ, Art. 223 Criminal Procedure Code).

\section{Pre-trial arrest}

The pre-trial arrest is a custodial preventive measure which involves the deprivation of liberty of the defendant over a certain period of time and his/her placement in specially arranged places (police stations, correctional facilities). The measure of pre-trial arrest is the harshest of these measures, and this is the reason it has an exceptional character. The measure of preventive arrest may be taken, prolonged or maintained only by a judge. Regarding the conditions for ordering the pre-trial arrest measure, it must be noted that they are identical to those to be met for ordering the house-arrest measure.

\section{Conclusions}

In the light of all the foregoing, we consider that the subject matter of the preventive measures is very well regulated, the Code of Criminal Procedure containing express provisions for the taking, extension, maintenance, revocation or termination of the law of such Measures.

Regarding the measure of preventive arrest, we consider that its character of exceptional measure must be respected and it is not sufficient for that character to be only theoretically stated. Even with an expedited reading of the judicial practice in this matter, we could note that the measure of preventive arrest has become a measure very facile ordered by the judicial bodies, the conditions laid down by art. 223 of the Code of Criminal Procedure being treated in an abstract and superficial manner. We believe that against the defendants who commit crimes the measure of judicial control should be most often applied, with the exception of those defendants who commit acts of violence and who pose a serious danger to public order. Precisely for stopping the performance of new offences by such persons the judicial control on bail has been regulated; the amount of bail money primarily aims at preventing new offences and ensuring the participation of the defendants in the criminal proceedings.

\section{References}

Cause Gusyinski v. Russia.

Cause Jecius v. Lithuania.

Causes Tuncer and Durmuș v. Turkey.

Law no 135/2010 on the new Criminal Procedure Code, published in the Official Gazette no 486 of July 15 , 2010, in force from February 1, 2014.

LegeAZ. "Art. 223 of the Code of Criminal Procedure." Available at https://legeaz.net/noul-cod-procedura-penalancpp/art-223.

Trancă, Ana Maria. 2017. Măsurile preventive (Preventive Measures). Bucharest: Hamangiu Publishing House.

Volonciu, Nicolae (coord.). 2017. Codul de Procedură Penală comentat (Code of Criminal Procedure commented). Bucharest: Hamangiu Publishing House. 